\section{Potassium Ion Stimulation of Hydrocarbon Oxidation by a Soil Corynebacterium sp.}

THE oxidation of straight-chain aliphatic hydrocarbons by a soil Corynebacterium sp. has been described previously ${ }^{3}$. The present communication demonstrates that the rato of hydrocarbon oxidation by washed suspensions may be stimulated markedly by potassium ions, which, however, have little effect on the oxidation-rate of possible intermediates.

Suspensions of the bacteria were grown either in a synthetic glucose broth deficient in potassium ions, or in nutrient broth, $p \mathrm{H} 7 \cdot 0$, incubated two to three days at $26^{\circ} \mathrm{C}$. on a shaking machino. The synthetic medium had the composition $10 \mathrm{gm}$. glucose, $3 \cdot 0 \mathrm{gm}$. ammonium nitrate, $1.5 \mathrm{gm}$. diammonium hydrogen phosphate, $0.25 \mathrm{gm}$. magnesium sulphate, $0 \cdot 1 \mathrm{gm}$. calcium chloride, trace amounts of ferrous, zinc, cupric, manganese and molybdat $\Theta$ ions per litre. The harvested cells were washed once with distilled water, shaken overnight at $26^{\circ} \mathrm{C}$. to reduce endogenous respiration, centrifuged and resuspendod in distilled water (1 $\mathrm{ml}$. suspension equivalent approximately $1.0 \mathrm{mgm}$. total cell nitrogen). 'The hydrocarbons were obtained from L. Light and Co., Colnbrook, England. Respiratory exchanges were measured by the Warburg technique at $27^{\circ} \mathrm{C}$. in $0.02 M$ tris (hydroxymethyl) amino methano buffer $p H \quad 7 \cdot 0.0 .05 \mathrm{ml}$. hydrocarbon was added from the side-arm.

The effect of potassium ions $(0.0008 M$ final) was tested on the rate of oxidation of $n$-hexadecane, $n$-tetradecane and $n$-decane by suspensions of Corynebacterium sp. harvested from potassium. deficient media. There was an initial lag period of low oxygen uptake during which potassium ions caused a slight but consistent inhibition of the oxidation-rate. The lag period varied from 1 to $2 \mathrm{hr}$., depending upon the hydrocarbon oxidized. There followed a marked stimulation of the rate by the added potassium ions. The respective overall oxygen consumptions in the presence of the $\mathrm{C}_{16}, \mathrm{C}_{14}$ and $\mathrm{C}_{10}$ paraffins were stimulated 231, 108 and 122 per cent by $0.0008 M$ potassium ions in $7 \mathrm{hr}$. No furthor stimulation was obtained by adding ten times this concentration of potassium ions. $n$-Octane was oxidized much more slowly, but after $7 \mathrm{hr}$. a net oxygen uptake of $125 \mu \mathrm{I}$. in the presence of potassium was observed, compared with $43 \mu 1$. in its absence.

The effect of other monovalent cations on hydrocarbon oxidation by potassium-deficient cells was investigated. $0 \cdot 0008 M$ ammonium ions, after $6 \frac{1}{2} \mathrm{hr}$. incubation, stimulated $n$-hexadecane oxidation even more than potassium ions (225 compared with 168 per cent). Rubidium ions were less effectivo (138 per cent). Caesium, sodium and lithium ions had no significant effect.

Similar results were obtained with $n$-decane as substrate, except that $0.0008 M$ ammonium ions had no effect upon the oxidation-rate, and rubidium ions only stimulated after $5 \mathrm{hr}$. incubation. In a separate experiment, however, it was shown that $0.008 M$ ammonium ions, after $4 \mathrm{hr}$, stimulated $n$-decane oxidation 111 per cent compared with 114 per cent stimulation by an equivalent of potassium ions. Rubidium ions $(0.008 M)$ again stimulated only after a lag period ( 35 per cent in $4 \mathrm{hr}$.).

The monovalent ions were added as their chlorides. The stimulation achieved is due to the cation, since identical results were obtained with equivalent amounts of potassium chloride, sulphate and nitrate.
Table 1. Stimulation of $n$-Decane Oxidation by Potassium Ions USING FRESH AND LYOPHILIJED CELLS OF Corynebacterium SP.

\begin{tabular}{|c|c|c|c|c|c|c|}
\hline \multirow{3}{*}{$\begin{array}{l}\text { Period } \\
\text { of } \\
\text { ageing } \\
\text { cells at } \\
4^{\circ} \mathrm{C} \text {. } \\
\text { (days) }\end{array}$} & \multicolumn{3}{|c|}{ Fresh cells } & \multicolumn{3}{|c|}{ Lyophilized cells } \\
\hline & \multicolumn{2}{|c|}{$\begin{array}{c}\text { Oxygen consumed } \\
(\mu \mathrm{l} .)\end{array}$} & \multirow{2}{*}{$\begin{array}{l}\text { Per- } \\
\text { cent- } \\
\text { age } \\
\text { stimu- } \\
\text { lation }\end{array}$} & \multicolumn{2}{|c|}{$\begin{array}{l}\text { Oxygen consumed } \\
(\mu \mathrm{l} .)\end{array}$} & \multirow{2}{*}{$\begin{array}{l}\text { Per- } \\
\text { cent- } \\
\text { age } \\
\text { stimu- } \\
\text { lation }\end{array}$} \\
\hline & $\begin{array}{c}\text { Decane }+ \\
0.008 M \\
\mathrm{~K}^{+}\end{array}$ & $\begin{array}{c}\text { Decane } \\
\text { only }\end{array}$ & & $\begin{array}{c}\text { Decane }+ \\
0.008 M \\
\mathbf{K}^{+}\end{array}$ & $\begin{array}{c}\text { Decane } \\
\text { only }\end{array}$ & \\
\hline $\begin{array}{l}0 \\
1 \\
3\end{array}$ & $\begin{array}{l}339 \\
346 \\
335\end{array}$ & $\begin{array}{l}282 \\
287 \\
280\end{array}$ & $\begin{array}{l}20 \\
21 \\
20\end{array}$ & $\begin{array}{l}307 \\
285 \\
270\end{array}$ & $\begin{array}{l}220 \\
159 \\
134\end{array}$ & $\begin{array}{r}40 \\
79 \\
102\end{array}$ \\
\hline
\end{tabular}

Each cup contained cell suspension $\equiv 0.52 \mathrm{mgm}$. cell nitrogen (non-lyophilized cells), or 0.42 mgm. cell nitrogen (lyophilized cells) in $2.5 \mathrm{ml} .0 .01 \mathrm{M}$ (flnal) 'tris' buffer $p \mathrm{H} 7 \cdot 0$, incubated
for $3 \frac{\mathrm{hr}}{0} ; 0.1 \mathrm{ml}$. $n$-decane was added from the side-arm.

The stimulation of hydrocarbon oxidation by potassium ions may be demonstrated in another way. Lyophilized cells of Corynebacterium sp. grown in nutrient broth showed a marked increase in potassium stimulation of $n$-decano oxidation, when aged in $0.025 M$ 'tris' buffer, at $4^{\circ} \mathrm{C}$., compared with identically treated cells of the same suspension which had not been-freeze-dried (Table 1).

The effect of potassium ions on the rates of oxidation of the aliphatic monohydric alcohols (range, ethanol to $n$-undecyl alcohol) and of the monocarboxylic acids (range, acetic to $n$-docylic acid) by potassium-deficient cells was investigated. 0.0008 $M$ potassium ions had no effect upon the oxidationrates, although identical concentrations of the cation caused a 244 per cent stimulation in $6 \frac{1}{2} \mathrm{hr}$. of oxidation of $n$-hexadecane by the same suspension. If the potassium ion stimulation of hydrocarbon oxidation is a direct effect upon one of the enzyme systems involved, then it would appear it must exert its influence before the formation of likely intermediates such as the fatty alcohols and acids. Further work with cell-free extracts is proceeding to this end.

I thank Miss G. Banos for technical assistance.

Division of Soils,

J. N. LADD

Commonwealth Scientific and

Industrial Research Organization,

Waite Agricultural Research Institute, Adelaide.

${ }^{1}$ Jadtl, J. N., Aust. J. Biol. Sci., 9, 92 (1956).

\section{Magnetically Induced Vortex for Small- scale Aerated Culture Studies}

THE advantages of aerating liquid cultures of bacteria to enhance the yield are well known. The use of sparger aeration techniques on a small scale is subject to certain disadvantages due to difficulties in sterilizing the air supply and controlling the frothing of the medium particularly when it contains serum.

Aeration by the production of a vortex in the medium has been described by E. B. Chain et al.' . This method provides a simple means of finely dispersing the air bubbles and at the same time automatically controls frothing. On a small scale such a vortex can easily be induced by means of a magnetic stirrer, thus obviating the necessity for sterile stirrer paddles and shaft seals. No forced air supply is required, the exchange through a conventional cotton-wool plug being sufficient for the organisms so far cultivated.

We have employed this method for the pilot-scale production of suspensions of Pasteurella septica, 